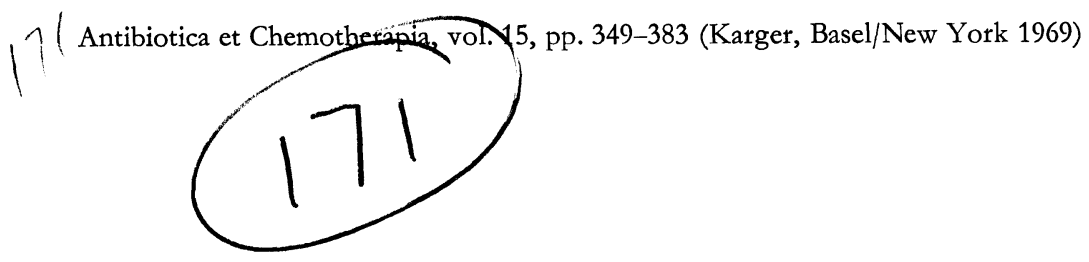

\title{
Perspectives in Organ Transplantation
}

\author{
T.E. Starzl, C.G. Groth, L. Brettschneider, G. V. Smith, \\ I. PenN and N. KashiwagI ${ }^{1}$ \\ Department of Surgery, University of Colorado School of Medicine \\ and Veterans Administration Hospital, Denver, Col.
}

Human kidney homotransplantation was first attempted on a large scale in 1962 and 1963. Even its most enthusiastic proponents could not then predict that this procedure would within five years become the preferred and the most effective way of treating patients with renal failure. Almost all previous trials had ended in the early death of the recipient [12] with the few notable exceptions recorded by Merrill [48], Hamburger [17, 19], Kuss [40], and Shackman [67]. There are today only two patients still alive who were treated before 1962, one from Boston and the other from Paris; both received kidneys from fraternal twins. Immunosuppression was with total body radiation, a technique of host conditioning which has been replaced in most centers by drug therapy. In contrast, successes in the succeeding years have been reported by many authors $[6,18,27,35,36$, $45,55,69,101]$.

In this report, several issues will be reviewed on the basis of our earlier experience with human renal transplantation. The questions to be examined in distant retrospect concern the homograft rejection seen after clinical renal transplantation and the measures necessary to control and reverse this process; the life expectancy of patients brought through early rejection episodes; the effect of prospective histocompatibility matching upon survival; and the early and delayed influence of thymectomy upon kidney transplant function. More recent developments will also be mentioned including the use of heterologous antilymphocyte globulin (ALG) in man, the role of the

1 Supported by United States Public Health Service grants AM-06344, HE-07735, AM-07772, AI-04152, FR-00051, FR-00069, AM-12148, and FO5-TW-1154. 
Shwartzman reaction in "hyperacute rejection", the development of neoplasms after transplantation, attempts to alter graft antigenicity with ribonucleic acid (RNA) infusion, and the extension of transplantation techniques to human liver replacement.

\section{Renal Homotransplantation}

The Reversal of Rejection and Subsequent Adaptation or Tolerance

One of the most important contributions of clinicians was the demonstration that rejection is a highly reversible process. This concept had not emerged from the skin graft experiments upon which the foundations of transplantation biology were largely based, nor was it evident in the first trials of either canine or human renal homotransplantation.

It is probable in retrospect that the Boston and Paris fraternal twins mentioned earlier both passed through rejection crises. The events in Hamburger's case [17] were the most clear. For almost three weeks after operation, the transplanted kidney functioned perfectly. Fever, azotemia, and proteinuria then developed, but within a ten day period these findings receded without the institution of any specific therapy. HAMBURGER ascribed the changes to a spontaneously reversible immunologic crisis.

Evaluation of the course in MERrILL's case [48] was made difficult by complicating circumstances. Immediate good renal function was also obtained. Within a few weeks, fever and a rise in BUN were seen, but at the same time the patient's own kidneys had cortical and perinephric abscesses. After nephrectomies and drainage, the deterioration was reversed and MerRILL concluded that "the oliguria and nitrogen retention... were clearly associated with an episode of infection". Eight months later, a homograft biopsy revealed mononuclear cell invasion and other morphologic evidence of chronic rejection. Although function was stable and essentially normal, additional total body irradiation was given as well as a course of adrenal corticosteroids. Their opinion at the time these observations were reported was that a rejection had been thereby "aborted"; it is now well known as will be discussed later that kidney grafts, found with late biopsy to have such histologic changes, may function for years without intensification of therapy and without clinically evident rejection $[61,78]$. In commenting on the significance and the earlier 
timing of events in Hamburger's case, Merrill said [48] “it seems highly unlikely... that in a partially tolerant patient, rejection would begin at the time at which it might be expected for the non-tolerant person, only to abort spontaneously".

The first suggestion that rejection was a highly controllable and reversible phenomenon came from our institution [82]. That report began as follows:

"Because of the high failure rate after renal homotransplantation, there has been an air of pessimism concerning the possibility of long term function of the grafted kidney. The immunologic processes subserving rejection are generally thought to be so powerful and persevering that consistent success cannot be expected with the use of any of the currently available methods of antirejection therapy.

Recent personal experience in caring for patients with renal homografts has resulted in alterations in many of our preconceived notions concerning the management of such patients. It has led to the beliefs that the rejection process can almost never be entirely prevented, but that its effects can be reversed with a high degree of regularity and completeness. Furthermore, the subsequent behavior of patients who have been brought through a successfully treated rejection crisis suggests the early development of some degree of host-graft adaptation, since the phenomenon of vigorous secondary rejection has been encountered only once."

In that series there were ten patients treated in late 1962 and early 1963. In seven, clear cut rejection of variable intensity occurred from 4 to 34 days after operation (fig. 1), in one case actually leading to anuria. In each instance, the process was reversed by the addition of massive doses of prednisone to the pre-existing therapy with azathioprine (fig. 1). Three of these 7 patients are still alive five or more years later and are now amongst the longest living recipients of nontwin homografts in the world. After the remarkable effectiveness of steroid therapy in this situation had been established from our own experience, but before our findings were published, it was learned that the same kind of observation had been made by Goodwin and his associates [11] in a young woman who ultimately died of sepsis 144 days after receipt of a maternal homograft. It was realized almost from the beginning that a reduction in homograft blood flow was an integral component of rejection crises and that the pharmacologically induced reversal was accompanied by relief of the organ ischemia $[69,77]$; both conclusions have been corroborated in animal experiments $[38,39,64,65]$.

The reversibility of rejection in these patients was only one of the features which established the clinical feasibility of organ transplantation. The quantities of adrenal corticosteroids necessary to achieve reversal were often extremely large, too great for reasons of toxicity 
to be compatible with long survival of the recipient if continued indefinitely. Fortunately, another event of equal practical importance transpired coincidentally with the reversal of rejection or shortly afterwards. With the passage of time, the need for intensive therapy usually diminished both in patients who did and those who did not pass through a clinically evident rejection. Thus, the patient whose course is depicted in figure 1 had returned within five months after transplantation to treatment only with azathioprine, a drug which at the outset did not prevent the onset of a moderately severe rejection. An ultimate similar reduction in drug requirement is today seen in almost all new cases and it is probable that some patients could

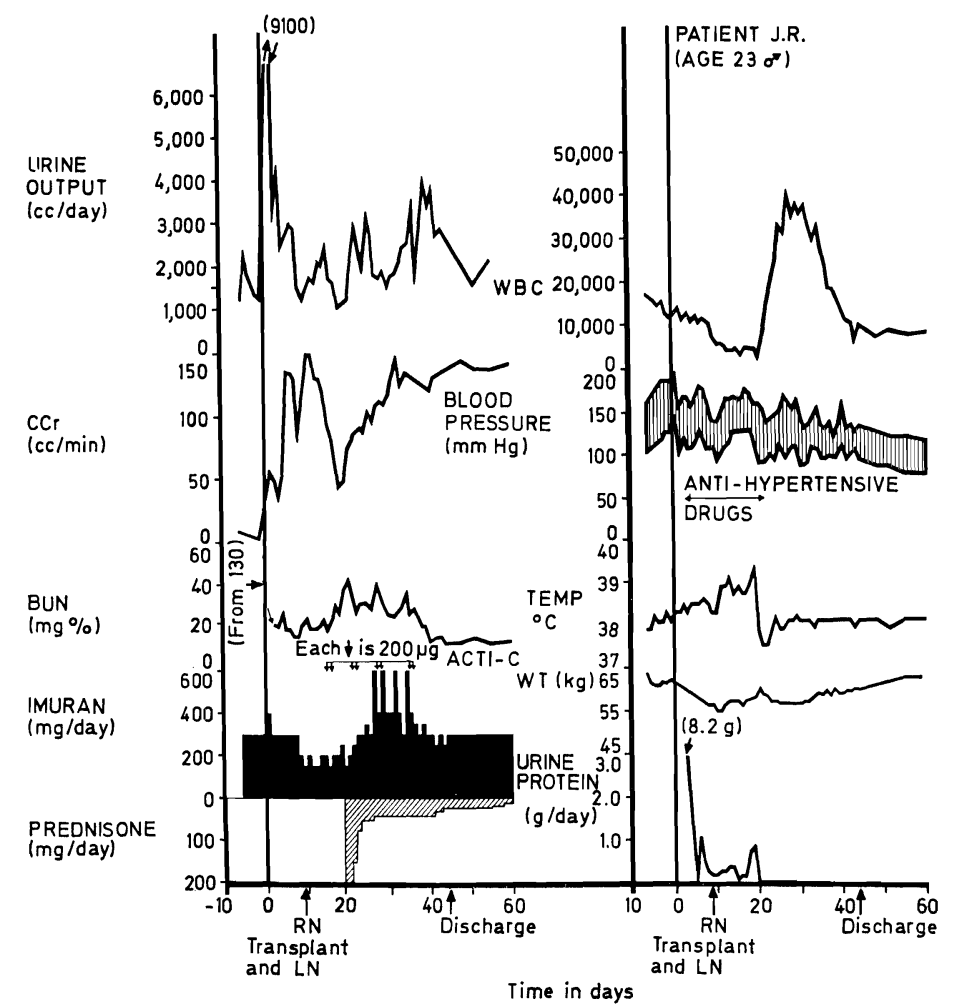

Fig. 1. Classical rejection crisis in patient (LD 6) treated with drugs alone. Deterioration of renal function began 19 days after transplantation. All stigmata of rejection were present except for acute hypertension and weight gain, which were successfully prevented by medical treatment. Acti-C---Actinomycin C; LN---Left nephrectomy at time of transplantation; RN---Right nephrectomy. Imuran is synonymous with azathioprine.

(By permission of Surg. Gynec. Obstet. 117: 385, 1963.) 
eventually have all therapy stopped. In our laboratory, we have dogs living for four to five years which were given treatment with immunosuppressants only for the first four months after receipt of life sustaining liver or renal homografts from non-related mongrel donors.

The foregoing phenomenon is so poorly understood that it is still reasonable to refer to it by the originally used term [82] of "a change in the graft-host relationship". Earlier animal experiments of WOODRUFF and WoODRUFF suggested that a metamorphosis occurs in transplants after long residence in a host [103], but, as McGavic and Murray of Boston showed [47, 54] by some other mechanism than an alteration in intrinsic graft antigenicity. Both MERrILL [48] and McGAvic [47] concluded that there was a host change (partial tolerance) but on the basis of observations $[47,48,54]$ that actually tended to support WoodruFF's point of view.

Whatever the explanation, there is no longer reason to doubt that a homograft becomes more or less privileged if it can be kept alive through the initial onslaught of rejection. This fact is detectable in the shape of life survival curves after renal homotransplantation in that the preponderant mortality is in the first few postoperative weeks or months when stringent immunosuppression is required. It has strongly influenced the way in which new therapeutic agents such as heterologous antilymphocyte globulin (ALG) have been used clinical$l y$, and it has been a prime stimulus for the extension of transplantation techniques to organs other than the kidney.

\section{Chronically Tolerated Renal Homografts}

Up-to-date reports about patients provided with renal homografts several years ago are still of vital current interest since this is the only data with which to obtain an idea of the long term prognosis of more recently treated recipients. Consequently, the cases compiled in Denver between the autumn of 1962 and March 1964 are particularly useful since it is the first series in which a large number of patients were successfully brought through the first few postoperative months. There were 64 recipients who received their kidneys from healthy volunteers; 30 (47\%) of that original group are still alive.

The most encouraging results were where intrafamilial transplantation was the original procedure. There were 46 recipients of consanguineous kidneys. Of these, 15 died within the first year, but only 1,1 , and 1 were lost during the second, third, and fourth postoperative 


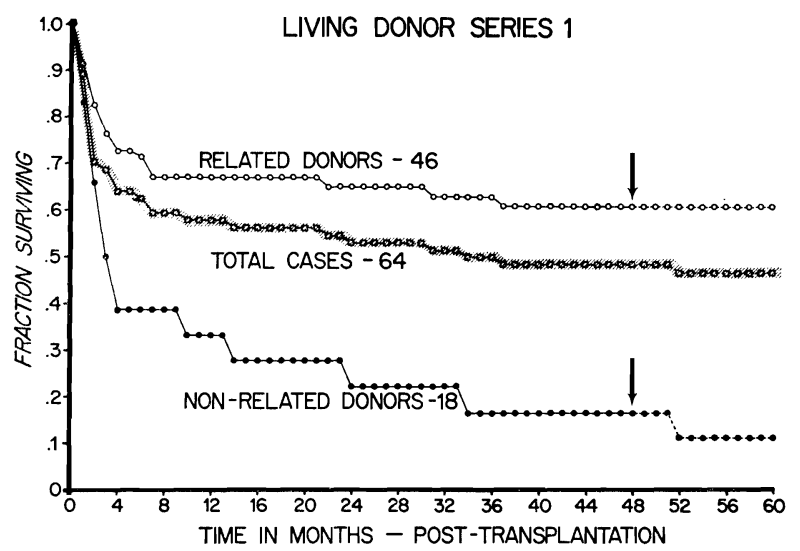

Fig. 2. Life survival curves of 64 patients treated in Denver with renal homotransplantation between November 1962 and March 1964. Preoperative histocompatibility testing was not done. The vertical arrows indicate the time of minimum followup.

years (fig. 2). The present survival after 4 to $5^{1 / 3}$ years is 28 of 46 $(60.9 \%)$. None of the 28 patients have received late retransplantation and none have been returned to dialysis programs. The function of these chronically tolerated homografts has been shown by OGDEN [57] to be generally almost as good as the contralateral kidneys left in their donors.

With recipients of non-related homografts, the picture was by no means as good. There was a heavier early mortality inasmuch as 12 of the 18 patients entered into the series had died by the end of the first year (fig. 2). Furthermore, a steady attrition continued thereafter. Two more patients died in the second postoperative year, as well as another two who reached 33 and 51 months respectively. There are now only two of the original 18 recipients alive, one by virtue of a second homotransplantation $2 \frac{1}{2}$ years after the first. The other patient has had continuous excellent function from his nonrelated homograft for more than four years.

The foregoing observations in a large series of transplantations have made it clear that survival for several years can often be obtained, particularly if related donors can be found. However, it can hardly be expected that most of these homografts will function for a normal lifetime since the presence in them of more or less serious structural abnormalities is the rule rather than the exception. This conclusion was reached by Dr. K. A. Porter of St. Mary's Hospital and Medical 
School, London, on the basis of examination of 2-year renal biopsies obtained from all Denver patients who survived this long [60, 61].

An occasional homograft was completely normal. However, in the others there were pathologic changes which were not always reflected in impairment of renal function. There were vascular lesions; fibrous thickening of the intima of interlobular arteries often with rupture or duplication of the internal elastic lamina, deposition of a hyalinelike substance in the subintimal layer of afferent arterioles and deposition of the same PAS-positive hyaline material in the glomerular capillaries. The last finding has been shown by HarLan et al. [20] to often be associated with a nephrotic syndrome.

The homografts with vascular lesions often had other secondary morphologic changes including fibrosis of the glomerular tufts, spotty periglomerular fibrosis, interstitial fibrosis, or tubular atrophy. The majority of the homografts also contained focal accumulations of mononuclear cells. Ten to $40 \%$ of these cells consisted of the pyroninophilic variety which are found in acutely rejecting homografts. In the chronically functioning homografts, the presence of such cells was not incompatible with good or even normal long term function.

Further studies by PORTER and his associates with immunofluorescence techniques and with ferritin-conjugated antisera have shed additional light on some of the foregoing changes [60]. The deposits in the subendothelial layers of small vessels and glomerular capillaries were shown to consist at least in part of host antibodies, particularly in the IgM class but also often including complement, IgG, and fibrinogen. These were considered to represent the reaction of circulating host antibodies with antigens in the capillary basement membranes of the transplanted kidney.

In three exceptional grafts, the deposits were nodular and were along the subepithelial side of the glomerular capillary basement membranes. The authors suggested that these were caused by the transmission of active glomerulonephritis from the recipient to the homograft [60]. Morphologic evidence that this sequence of events was possible had previously been published by PORTER [62], O'BrIEN and Hume [56], and Petersen $e$ t al. [59]. More recently, Lerner et al. [43] have conclusively shown that anti-glomerular basement membrane (anti-GBM) antibodies present in the serum of a patient with active glomerulonephritis fixed to and adversely effected a subsequent transplanted homograft. Presumably, this complication could be avoided if patients with acute or subacute glomerulonephritis were 
subjected to preliminary nephrectomy and transplantation were then deferred until recipient serum levels of anti-GBM antibody disappeared.

The fact that many, or even most, renal homografts may gradually fail is not a serious argument against further clinical transplantation. The degree of social and vocational rehabilitation in the interval of satisfactory kidney function is usually relatively complete. Moreover, it is now known chiefly as the result of Hume's work [27], that retransplantation for the indication of a failing first homograft can be done with a reasonable expectation of success. This expedient was considered too late in some of the patients in our early series who died long after operation with diminishing renal function.

\section{Histocompatibility Typing}

During the time when the first Denver series was accumulated, there were no practical methods of predicting the vigor or tenacity of the anticipated rejection process. It was quickly recognized that red blood cell group incompatibilities between donors and recipients could lead to immediate loss of the transplanted kidneys, from which experience the now widely accepted rules were formulated $[69,75]$ concerning tissue transfer between people of different ABO types (table I). Since other preoperative analyses of donor-recipient compatibility were not available, the transplantation itself became a test system in which, presumably, the recipients of biologically unfavorable kidneys were ruthlessly weeded out in the early mortality. It was decided to retrieve the information derived from this unacceptable situation and use it to try to improve donor selection for future cases. The effort involved a collaboration with Dr. P. Terasaki of Los Angeles, and Dr. K.A. Porter of London, England. In the meanwhile, a six month moratorium on new cases was declared.

For some years, Terasaki, Dausset, Payne, van Rood, CepPELLINI, AMOS, and others [23] had been working on the characterization with a variety of serologic techniques of the antigens contained in leukocytes. These workers were convinced that most of the antigens contained in renal and other tissue were also to be found in the readily accessible peripheral lymphocytes. By studying the lymphocytes of prospective donors and recipients, it was hoped that an idea could be obtained of their general tissue compatibility. Unfortunately, there was at that time no proof that the antigen systems under investigation 
had any direct or indirect relationship to histocompatibility and it was to establish this point that the Denver patients were employed.

First, TERASAKI analyzed the antigenic constitution of a number of surviving recipients and their donors using his lymphocyte cytotoxicity test. The quality of the matches was graded and compared with clinical rankings accorded by those caring for the patients. The correlation was imperfect. It was evident that many patients had retained good homograft function for long periods in spite of what appeared to be poor matches with their donors. Nevertheless, most of the really superior clinical results were in patients who had received exceptionally well matched kidneys [78, 91]. Later, a far more striking correlation was found between the Terasaki results and the degree of histologic injury noted by PORTER in the two year biopsies mentioned in the preceding section [61].

Although much of the above-cited support for the validity of antigen typing was not yet available in 1964, there was even then enough favorable evidence to warrant a prospective clinical evaluation. When transplantation was resumed in October of that year, an effort was made by TERASAKI in every case to find the best possible donor amongst the volunteers available for each patient.

The selectivity was severely limited in most cases of intrafamilial transplantation. In most instances, only one or two blood relative were willing to donate or were acceptable on general medical or psychiatric grounds. Consequently, the matching was not improved to a statistically significant degree over that which could have been achieved with random intrafamilial pairing [88]. It was not, therefore, surprising to find that the ultimate survival in these related cases (fig. 3) was almost identical to that defined in the earlier Series I. Of 25 recipients, $16(64 \%)$ were still alive at one year. Two more subsequently died after 26 and 30 months leaving a residual group of 14 ( $56 \%$ ) with a follow-up of 23 months to $3 \frac{1}{2}$ years.

In the 17 non-related homotransplantations, the situation was different in that donors were picked from a pool which included as many as 80 volunteers. Perfect matches could not be found, but the quality of the pairing was improved over that which could have been expected by chance [88]. The recipients fared better than previously observed in Series I. Nine (52.9\%) of the 17 recipients were still alive at the end of the first year (fig. 3). Three more patients were lost at 18,27 , and 35 months respectively but in two of these there was life sustaining renal function until death. Six of the 17 patients $(35.3 \%)$ 


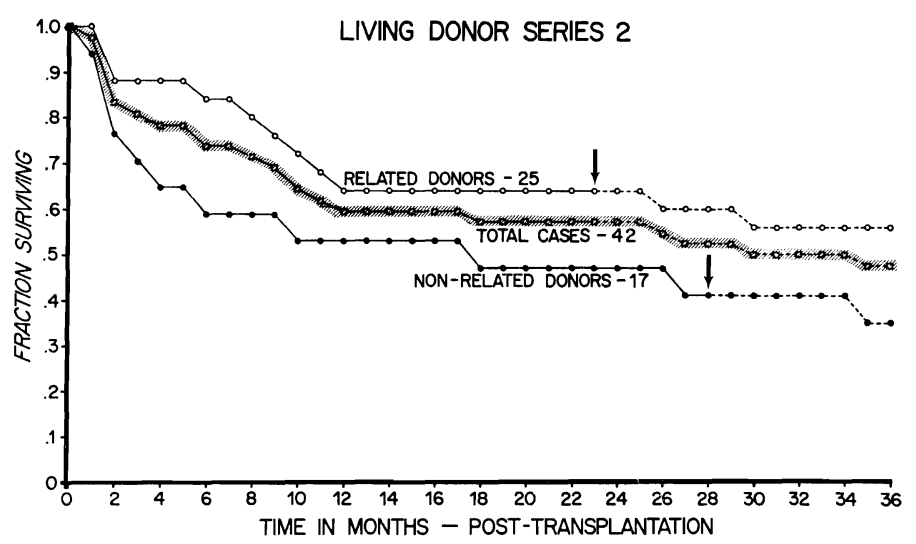

Fig. 3. Survival of 42 patients treated with renal homotransplantation between October 1964 and April 1966. An attempt was made by TerASAKi to select the most compatible donor amongst available volunteers. See text for discussion of results.

are still living with good to excellent function of their original homografts from 28 to 40 months after transplantation. The mean creatinine clearance in the remaining group is $83.4 \pm 26.2$ (SD) $\mathrm{ml} / \mathrm{min}$.

In both the related and non-related cases, observations were made which were similar to those made retrospectively in Series I. Several recipients of poorly matched kidneys fared surprisingly well. A few patients with good matches experienced vigorous and prolonged rejection. However, the preponderance of the best results were in cases in which a close antigen match had been present.

The failure to improve survival at all in the related transplantations or to increase it more in the non-related cases was a keen disappointment since evidence from many investigators now suggested more strongly than ever that the tissue typing being used provided a measure of histocompatibility antigens $[7,41,58,63,83,90,93,98]$. It seemed that safer methods of immunosuppression would be required before histocompatibility typing could receive a fair trial.

It had been recognized for several years that many and possibly even most of the deaths after clinical homotransplantation were due to drug toxicity. At the beginning, bone marrow depression from overdoses of azathioprine had been common, but with increased experience this complication was now rarely seen. Avoidance of the hazards of the steroid therapy which is usually combined with azathioprine was not so simple. In many cases, it had been found that continued function of a homograft was dependent upon continuation 
for long periods of unacceptably large quantities of prednisone. The complications which followed were exceedingly troublesome at best, and lethal at worst. These included cosmetic deformity, bone demineralization often with spontaneous fractures, muscle wasting, arrest of growth in infants, fatty infiltration of the liver, pancreatitis, and gastrointestinal ulceration and hemorrhage to name just a few. Most serious, however, was the consequent susceptibility to microorganisms of all types.

If the resultant infections were due to common pathogenic bacteria they could be treated effectively with properly chosen antibiotics. Very often, however, these were caused by fungi, protozoa, or viruses for which specific therapy was not available. The tragic consequences are illustrated in figure 4. This patient, who received a homograft from his brother, had an early rejection crisis followed by excellent renal function for the next nine months. After reduction of his prednisone to $10 \mathrm{mg} /$ day, he had a delayed rejection which was controlled by increasing the prednisone dose to a level from which

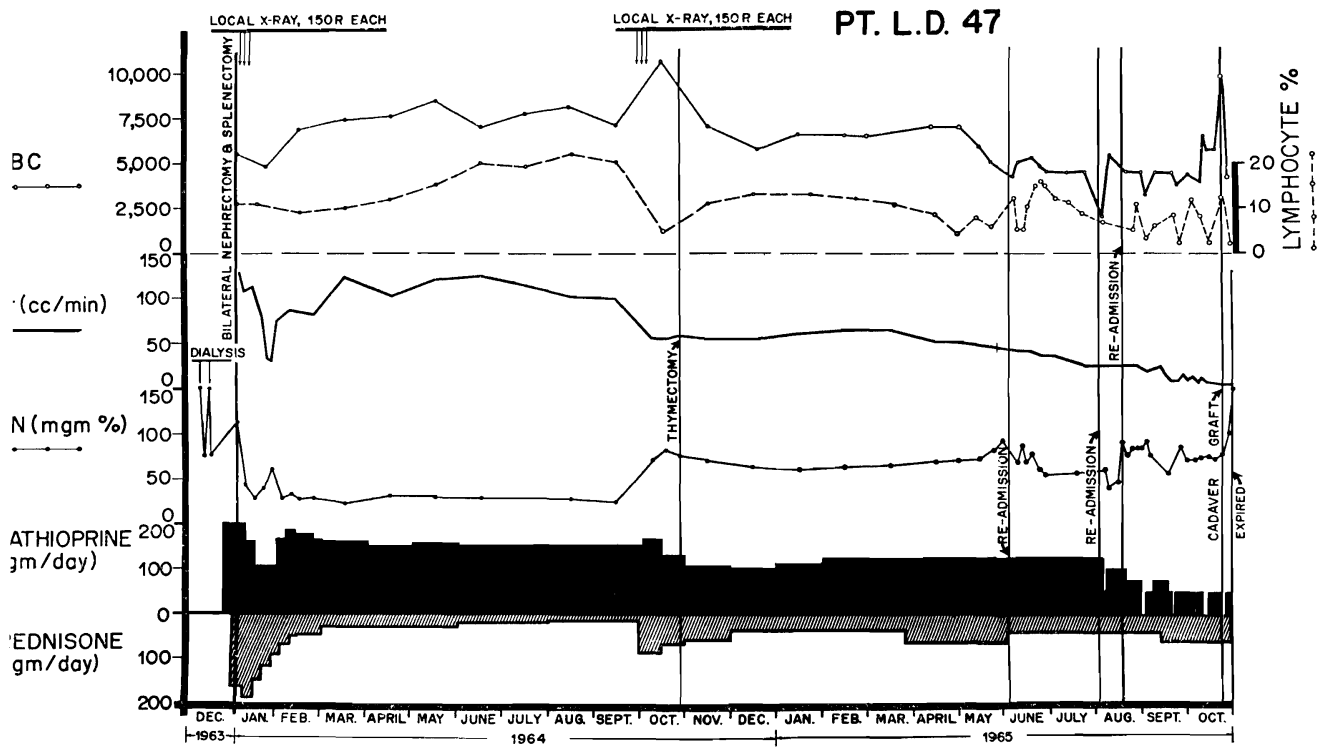

Fig. 4. Course of a 37-year-old man (LD 47) who received a kidney from his younger brother. Both were $\mathrm{A}^{+}$blood type. Note the severe late rejection after nine months and the subsequent slow deterioration of renal function. The late thymectomy did not induce either lymphopenia or make the subsequent management easier; the post-thymectomy changes in lymphocyte counts were related to adjustments in steroid dosage. (By permission of Ann. N.Y. Acad. Sci. 129: 605, 1966). 
subsequent withdrawals were not possible without further deterioration of kidney function. He died 15 months later but not primarily from renal failure. He had fatty infiltration of the liver, a duodenal ulcer, and pancreatitis. There were cytomegalic inclusion viruses in the lungs and liver, and diffuse pneumonitis due to Pneumocystis carinii and Aspergillus fumigatum.

\section{Improvements in Immunosuppression}

For the aforementioned reasons, intensive efforts have been made in a number of laboratories to develop new and safer immunosuppressive agents. The most encouraging results have been with heterologous antilymphocyte serum (ALS) or its globulin derivative (ALG). These biologic agents were first evaluated in animals for their ability to prevent rejection by WAKSMAN et al. [95] and WoODRUFF and ANDERSON [102]. Notable contributions have since been made by MonACO and Russell and their collaborators [13, 51, 52], Levey and MEDAwAR [44], and many others [100].

In our laboratory, the horse has been used as the source of immune serum $[28,76]$. After immunization with the lymphoid tissue of the species to be eventually treated, the horses are bled and the serum is separated. Undesirable anti-red cell and anti-plasma protein antibodies are absorbed with donor species red cells and plasma or serum. The antilymphocyte antibodies which are in the IgG fraction of the horse serum can then be removed with several techniques. Initially, we employed ammonium sulphate precipitation for crude globulin extraction (fig. 5) but more recently pure IgG has been removed in bulk quantities (fig. 6) by batch mixing with DEAE cellulose [33]. The ALG can then be given by intramuscular injection.

The guidelines for the clinical use of heterologous ALG were provided by extensive investigations in dogs. The ability of the antidog-lymphocyte globulin to mitigate homograft rejection was easily and unequivocally demonstrated $[74,76]$. Nevertheless, the degree of protection was incomplete. In about a fourth of the animals rejection proceeded as might have been expected in untreated animals. Its onset was delayed or occasionally prevented altogether in the rest of the animals. However, survival of as long as 4,8 , or 12 months was observed in the minority of recipients of kidneys or livers. This spectrum of results was similar to that which can be obtained in dogs with other potent immunosuppressive agents such as azathioprine. 

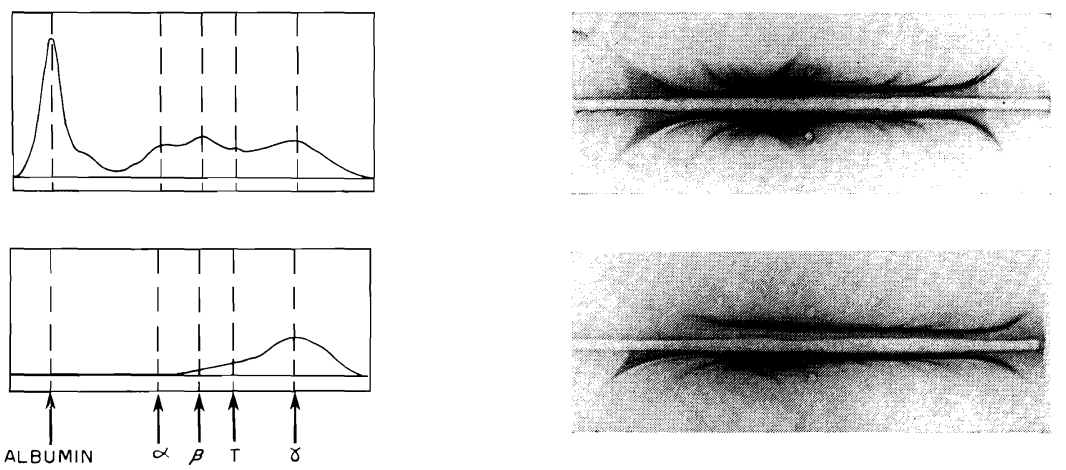

Fig. 5. Electrophoresis and immunoelectrophoresis of absorbed antihumanlymphoid serum and the protein obtained from it by two precipitations with 0.4 saturated ammonium sulphate, two dialyses, and lyophilization. The final product, which was used clinically, consisted mostly of gamma $\mathrm{G}$ globulin but it usually contained small quantities of alpha and beta globulins. (By permission of Surg. Gynec. Obstet. 124: 1, 1967.)
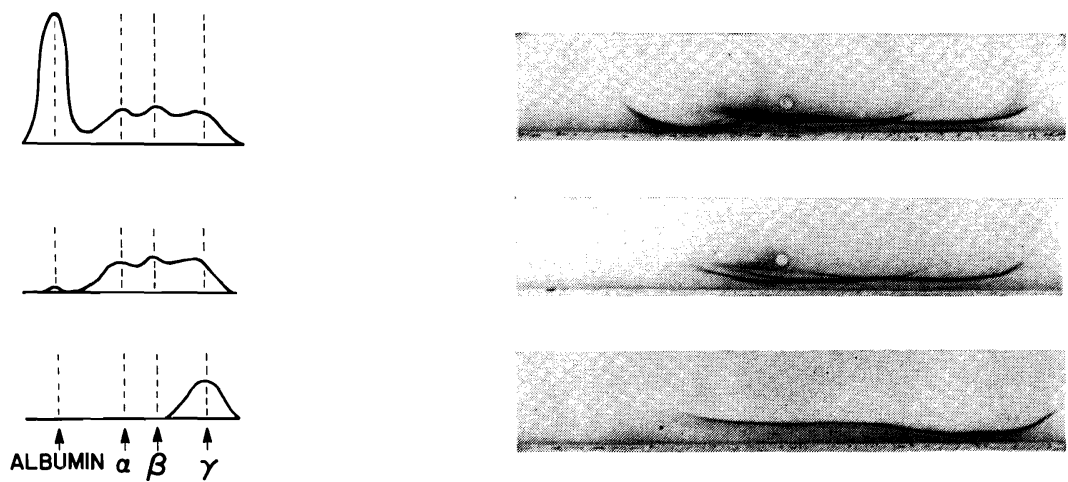

Fig. 6. Electrophoretic and immunoelectrophoretic patterns of unabsorbed antihuman ALS, the raw globulin obtained with a single ammonium sulphate precipitation of absorbed ALS, and the final product (pure gamma G globulin) after subsequent DEAEcellulose batch extraction.

Other factors concerned with the toxicity of ALG influenced the therapeutic program finally adopted $[28,72,76,81]$. After long term administration, the animals usually developed antibodies against the injected horse protein. Many of these dogs ultimately had microscopic renal lesions which consisted of deposits of horse protein, together with host gamma globulin and complement; the findings were characteristic of serum sickness nephritis [28]. 
For all these reasons it was decided to use ALG only as an adjuvant to the standard immunosuppressive agents azathioprine and prednisone. The regimen ordinarily followed is shown in figure 7. ALG was started a few days in advance of transplantation, continued daily for the first 10 to 14 postoperative days, then every other day for two weeks, twice a week for two months and once a week for a final month. The four month duration of the ALG course was selected since the greatest need for improvements in therapy was in this postoperative period of high risk. It was anticipated that an at least partial evolution of the state of "host-graft non-reactivity" discussed earlier would have occurred by the end of this time and that the need for maintenance treatment would be correspondingly reduced.

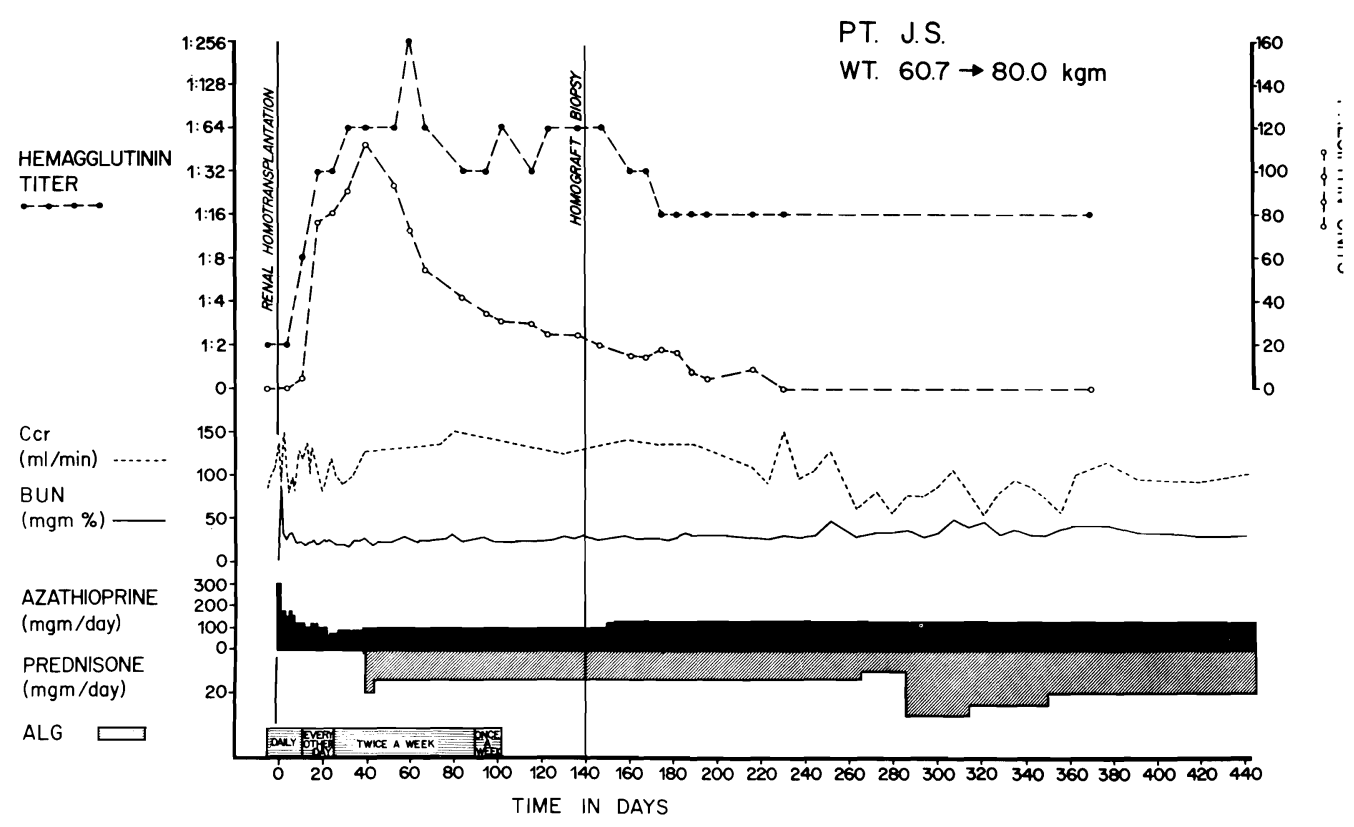

Fig. 7. The course of a patient who received antilymphocyte globulin (ALG) before and for the first four months after renal homotransplantation. The donor was an older brother. The Terasaki match was a good one. There was no early rejection. Prednisone therapy was started 40 days postoperatively because of the high rises in the serologic titers which indicated a host response against the injected foreign protein and which warned against a possible anaphylactic reaction. Note the insidious onset of late rejection after cessation of globulin therapy. This was treated by increasing the maintenance dose of steroids. This delayed complication was seen in only two of the original 20 patients whose survival is shown in figure 8. (By permission of Surg. Gynec. Obstet. 126: May, 1968.) 
The first patient was treated in this way in June 1966. From then until the following December, 19 more were added to the series One of the patients died during the second postoperative month as the direct consequence of a technical surgical accident. The others are alive with good renal function from their original homografts from 15 to 21 months later for a current survival of $95 \%$. An additional 45 patients have since been treated with comparable results.

The ALG-treated recipients received kidneys from blood relatives. The results obtained in the first ALG series are shown graphically in figure 8 and compared with those obtained in previous intrafamilial transplantations in our institutions. For the latter purpose the consanguineous transplantations in the original Series I were divided into two consecutive groups, now termed Series $1 \mathrm{~A}$ and $1 \mathrm{~B}$; this was done to evaluate the effect of increased experience upon results. The intrafamilial homotransplantations described in the above section on histocompatibility typing were Series 2 . In each of the consecutive earlier series the mortality in comparable follow-up intervals had been from 28 to $31 \%$.

The explanation for the improved results in the ALG-treated patients was not better histocompatibility matching as has been documented elsewhere in detail $[72,81]$. The apparent reason is shown in figure 9. During the time when the sequential earlier series

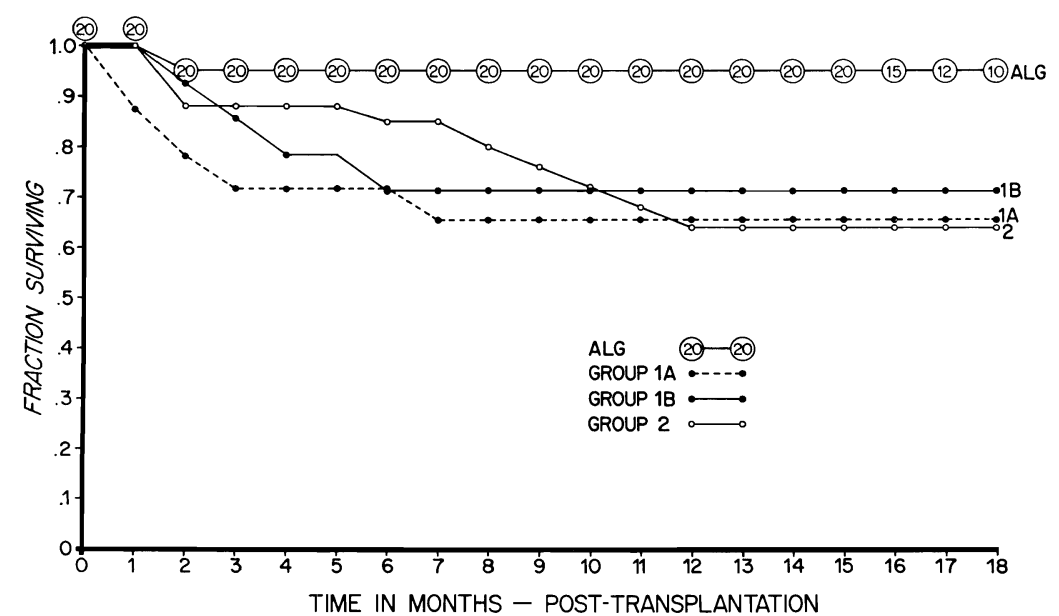

Fig. 8. Survival curve of the first 20 patients treated with antilymphocyte globulin (ALG) compared to that in three previous series of consanguineous transplantation at our institutions. Followups in the globulin-treated group are 15 to 21 months. The numbers in the upper curve indicate the patients at risk for each monthly interval. 


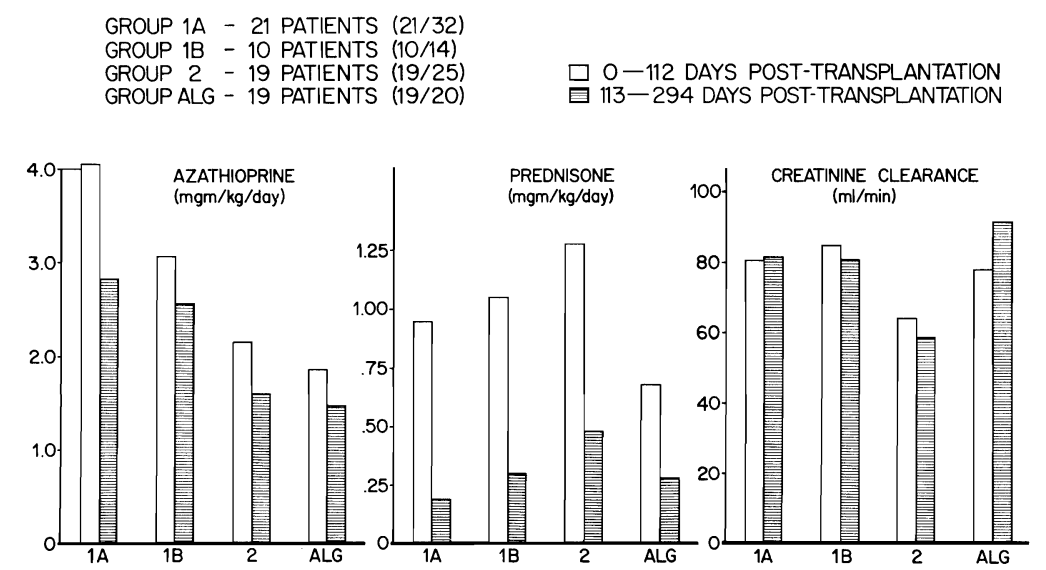

Fig. 9. The average azathioprine and prednisone doses per $\mathrm{kg} /$ day and the creatinine clearances for the first 16 postoperative weeks (shaded) and for the subsequent six months (solid). Shown are the retrospective control series (Groups 1A, 1B and 2) and the ALG series (Group 3). Inclusion in the analysis was contingent upon survival for 294 days, a condition which was met with the highest regularity in the ALG patients.

were being accumulated, there had been a progressive tendency to use smaller doses of azathioprine both during the first four and the subsequent six postoperative months. This trend continued into the ALG series.

However, as the average doses of azathioprine were cut, there had been compensatory increases in the quantities of prednisone which were necessary to maintain a somewhat poorer quality renal function (figure 9, middle and right). The result of the slowly evolving adjustments in policy was a change in the causes of death as described from our institutions by HiLl et al. [22]. The early mortality from bone marrow depression and pyogenic infections was virtually eliminated. This was replaced by a delayed mortality which was usually due to untreatable infections caused by unusual opportunistic microorganisms.

The situation was drastically reversed in the ALG-treated patients in that the quantities of average daily prednisone could be sharply lowered during the first four postoperative months when ALG was being given. Furthermore, the steroid doses remained at acceptably low levels in the next six months after the ALG had been stopped. The ability to reduce the stringency of therapy with both azathioprine and prednisone was not paid for with a loss of renal function (fig. 9, right) since all measures of renal function in the ALG-treated patients were at least as adequate as in the earlier series. 
The extremely favorable showing of the ALG as compared to earlier series was in spite of a sharp bias introduced by the method of analysis. Inclusion of any case in the studies shown in figure 9 was contingent upon survival for ten months. A substantial fraction of the worst patients in each of the retrospective series were thereby eliminated by their death. Inasmuch as only one of the 20 patients in the ALG group was similarly excluded, the latter series was much less selective.

This experience with ALG suggests that its use as an immunosuppressive agent has improved the management of patients after transplantation. However, there have been a number of side effects, recently summarized by KASHIWAGI et al. [32]. Sensitization to the repeatedly injected horse protein has in time led to a number of skin rashes. Fever and pain at the injection sites were invariable. In nearly $20 \%$ of cases an anaphylactic reaction occurred at some time during the course of therapy. The most serious of these adverse effects usually were observed when titers of host precipitating antibodies had reached high levels. Interestingly, the easily detectable antibodies were directed against the alpha and beta globulins which were present in small quantities in the ALG; only rarely were precipitins found against the equine gamma $G$ globulin which is thought to be the biologically active part of ALG. Consequently, there is reason to hope that the pure gamma $G$ globulin $(\operatorname{IgG})$ which is now being produced in bulk as discussed earlier will eliminate some of the undesirable features of ALG.

One of the most disquieting possibilities with the clinical use of heterologous ALG was that the renal homografts would become the site of serum sickness or direct nephrotoxic Masugi-like nephritis. This fear has been largely dispelled. The first 8 patients treated with ALG received homograft biopsies at the end of their 4-month course of therapy. The specimens were studied with immunofluorescence and ferritin-labeled antibody techniques [81]. There was no trace of horse protein. Since then four more kidneys have been studied. In only one was there detectable horse protein, and in that patient there has been no clinical or biochemical evidence of serum sickness nephritis.

\section{Thymectomy in Clinical Transplantation}

In adult mice, rats, and hamsters the performance of complete thymectomv causes a slowly developing loss in immunologic reactivity in 
otherwise unaltered animals $[49,50,68,86]$. The process can be accelerated in skin homotransplantation experiments if immunosuppressive therapy is given either with total body irradiation $[9,49]$ or with antilymphocyte serum $[29,51]$.

Shortly after the appearance of the first of the above reports, eight patients were subjected to thymectomy at our institutions 14 to 85 days before renal homotransplantation. Four of the patients died within a few weeks or months after receipt of their homografts. The other four are still alive more than five years later, all with excellent renal function. As has been previously stressed [78, 79], the role of thymectomy in the attainment of long term graft function in these cases was essentially unanalyzable.

In order to clarify this issue, a formal study of the effect of thymectomy was carried out in 46 more patients who were treated with renal homotransplantation from October 1964 until June 1966. All kidneys were provided by living donors of whom $37 \%$ were unrelated. A decision for or against thymectomy was made on the basis of random selection from appropriately marked cards. The spectrum of histocompatibility typing as well as a number of other variables proved to be almost identical in the 22 control cases as compared to the 24 cases in which transthoracic thymectomy was carried out before transplantation.

The duration of follow-up for these cases is now from 21 to 41 months. The results were assessed on the basis of early and late mortality (fig. 10), the dosages of immunosuppressive drugs necessary to retain stable homograft function, and the quality of both early and late renal function. There were no statistically significant differences between the thymectomized and non-thymectomized groups in any of these measures. In all 46 cases samples of the transplanted kidneys are now available for examination either as a result of autopsy or late biopsy. The histopathologic examination has not yet revealed clear differences between the test and control series of kidneys, although the specimens are currently being reviewed for the possibility that there may be subtle differentiating features.

At the moment, however, it can be concluded that an important benefit did not derive from thymectomy. This does not, of course, prove that the thymus has no immunologic function in adult man. At the least, however, it does indicate that other factors are so much more important in determining survival and homograft function that the loss of the thymus resulted in no detectable changes under the 


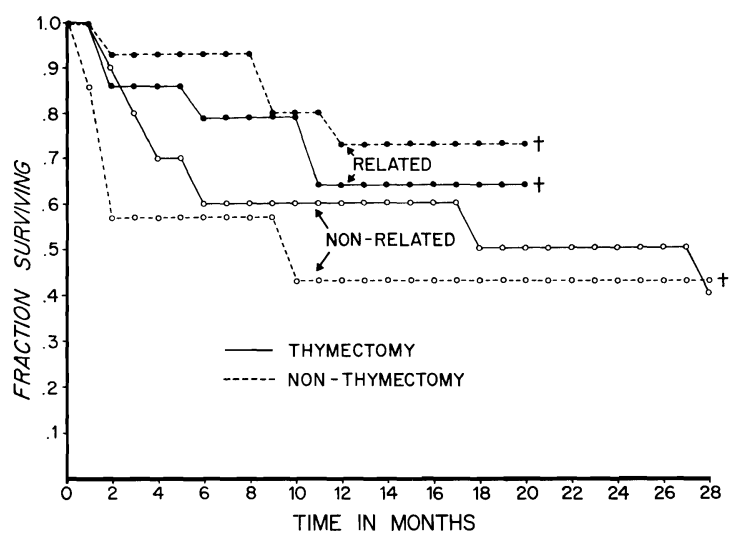

Fig. 10. Life survival curves of 24 patients who received pretransplantation thymectomy and 22 patients who did not. The minimum followup is 21 and 28 months in the related and non-related groups respectively. The crosses indicate that one additional patient in each of the three groups subsequently died after the period shown. Note that the thymectomy did not influence either the short- or long term survival.

experimental conditions which existed from 1964 to 1966. Conceivably future improvements in management might permit unmasking of a presently unrecognizable subtle effect of thymectomy but, at present, there seems to be no justification for the continued use of the procedure in clinical organ transplantation.

\section{Post-Transplantation Neoplasia}

In 1966, Schwartz et al. [66] described the development of malignant lymphomas after homotransplantation of lymphoid tissues in mice; the genesis of the neoplasm was thought to be related in some way to a subclinical graft-versus-host reaction. They stated: "The practical importance of these findings to those attempting the transplantation of allogenic bone marrow or lymphoid tissue remains to be determined. Nevertheless, it might be appropriate to consider them along with other possible hazards of tissue transplantation".

Two of our recipients of renal homografts have developed and died of reticulum cell or lymphosarcoma, and it is known that Dr. C. Hiтснсоск [24] of Minneapolis has had a similar patient. The close resemblance of the human tumors to some of those induced by SCHWARTZ et al. in animals could conceivably be more than a coincidence. If so, these may be the first clinical examples of a new and serious complication of transplantation, 
The three cases had in common the facts that consanguineous kidneys were transplanted (brother, father, and mother), that the donors have not subsequently had evidence of neoplasia with followups of one to four years, and that the recipients were young (14 to 27 years) and all received immunosuppression with azathioprine and prednisone. One of the patients had thymectomy before transplantation. Another received heterologous antilymphocyte globulin (ALG) before and afterwards. The third received neither of these adjuvant measures. The malignancies led to death 6 months, 14 months and $21 / 2$ years after homotransplantation. It was not possible to determine where the tumors originated but the major sites of involvement were the brain in one patient, the liver in another, and the liver and lung in the third.

In connection with Schwartz's hypothesis of a graft-versus-host etiology of analogous neoplasms in mice, it is of interest that a small amount of lymphoid tissue is invariably transferred with renal homografts. This was well demonstrated by the studies of WiLson and KIRKPATRICK [99] who showed that delayed hypersensitivity reactions present in donors were always transferred to previously negative recipients and there persisted for months.

\section{Hyperacute Rejection}

As mentioned earlier, it was soon learned that renal homografts had a significant risk of being immediately destroyed if the donors and recipients had different $A B O$ red cell groups in the combinations shown in table I. A rational explanation was available since the isoagglutinogens which allow red cells to be typed are also found in other tissues including the kidney $[26,85]$. Thus if the kidney of an

Table 1 . Direction of acceptable mismatched tissue transfer ${ }^{1}$

\begin{tabular}{ll}
\hline $\begin{array}{l}0 \text { to non-0 } \\
\mathrm{RH}-\text { to } \mathrm{RH}+ \\
\mathrm{RH}+\text { to } \mathrm{RH}-\end{array}$ & $\begin{array}{l}\text { Safe } \\
\text { Safe } \\
\text { Relatively Safe }\end{array}$ \\
\hline & \\
\hline A to non-A & Dangerous \\
$\mathrm{B}$ to non-B & Dangerous \\
AB to non-AB & Dangerous \\
\hline 10 is universal donor; AB is universal recipient. & \\
\hline
\end{tabular}


A or $\mathrm{B}$ donor were placed in a patient of 0 blood type, the naturally occurring anti-A and anti-B isoagglutinins respectively in the serum of the recipient could be expected to bind with the renal red cell antigens; serologic studies by WiLsON and KIRKPATRICK provided strong evidence that this actually occurred [99].

In cases where the homografts were immediately lost, the sequence was typical. After opening the renal vessels, the kidney cortex was not well vascularized although the medulla, pelvis, and ureter apparently had a good blood supply. These soft and cyanotic kidneys which were removed within a few hours had histologic evidence of widespread small vessel thrombosis [69]. A frank red cell group mismatch did not always lead to this kind of accident. One of our patients has normal renal function more than five years after transplantation under such circumstances.

Recently, there have been reports of similar catastrophes where there was conformity of red cell types. The first case was described briefly by TerASAKr [87] and others were added by KissmeYerNielsen [37], Williams [96, 97], and Terasaki [89]. In the serum of many but not all of these patients preformed antibodies were present preoperatively which reacted against donor white cells. This fact has resulted in speculation that such antibodies were directly responsible for the homograft destruction by virtue of a high grade nephrotoxicity $[37,96]$. Our own studies on "hyperacute rejection" in the absence of red cell mismatching, carried out in collaboration with R. Lerner and F. Dixon of La Jolla, California, have led us to a different conclusion as recently reported in detail [73]. In five kidneys which sustained "rejection on the operating table", there was unequivocal evidence of a generalized Shwartzman reaction. With immunofluorescence techniques, LERNER and Dixon found massive fibrin deposition in the small vessels and glomerular capillaries and consequent cortical necrosis exactly as in an experimentally induced Shwartzman reaction. There was little or no immunoglobulin deposition detectable by immunofluorescence [73] although eluates of some of the kidneys were later shown by Dr. F. Milgrom of Buffalo, New York, to contain leukoagglutinins. In three of the five instances, the kidney donors had been shown by TERASAKI to have a good histocompatibility match with the recipients.

The generalized Shwartzman reaction was first described in 1934, but its significance as summarized by LEE and STETSON [42] and HJORT and RAPAPORT [25], was not understood until the last decade. Clas- 
sically, it is produced in rabbits by two injections of endotoxin spaced at $24 \mathrm{~h}$ intervals. A generalized coagulapathy is produced. If the animal reticuloendothelial system (RES) can clear the breakdown products of fibrinogen rapidly enough, the kidney is spared from injury. If not, it becomes a primary target because the specific qualities of the renal microcirculation make it an exceptionally good fibrin filter. The result is cortical devascularization and necrosis.

A number of factors besides endotoxin can condition or precipitate a Shwartzman reaction, including antigen-antibody reactions; injection of thorotrast, carbon black, or steroids; or administration of an oxidized lipid diet. Their effects are incompletely understood but presumably they could be influential by either reinforcing the coagulapathy and/or by reducing the efficiency of RES function, or by suppressing counter-regulatory fibrinolysis.

In several ways, the recipient of a renal homograft could be expected to be a good candidate for a Shwartzman reaction. Before operation, he undergoes multiple hemodialyses with attendant risks from accidental exposure to endotoxin in the extracorporeal circuit [34], from an additional loss of RES efficiency caused by increased blood hemolysis [5] and other factors of extracorporeal circulation [84], and from the rapid changes in coagulation which occur with this procedure [94]. With multiple blood transfusions, there is an increased chance that he will develop antibodies against antigens in infused white blood cells or red cell subgroups, and that these will later react with the same antigens in the homograft. The operation itself introduces the latter possibility as well as that of a full spectrum of other potential triggering antigen-antibody reactions either within or outside the freshly transplanted kidney. Intra- and postoperatively steroids, which can potentiate a Shwartzman reaction by causing RES paralysis [92], are commonly used.

Recognition that many, and possibly even most, "rejections on the operating table" are due to Shwartzman reactions has practical implications. Prophylactic measures can be taken. Greater attention can be paid to the details of hemodialysis including asepsis and hemolysis rates. The value of white cell free blood for transfusion is obvious. Immunologic tests to detect presensitization are available; when such an examination is positive in a recipient, the hazards are predictably increased [89, 97]. Under these circumstances, it may be advisable to use total body heparinization at the time of transplantation. This was done in two of our patients whose previously placed kidney 
transplants had been immediately destroyed; the final homografts functioned well [73]. Once a Shwartzman reaction has started, a combination of heparin and fibrinolysin therapy might be worth a trial.

It is probable that most and perhaps even all Shwartzman reactions are ultimately triggered by antigen-antibody unions of one sort or other at the time of transplantation. If these are intrarenal, they may be inherently benign or even undetectable with immunofluorescence studies as in our cases and of significance only by virtue of the devastating secondary effects which they can initiate depending upon a variety of other conditions. If, as is now thought, the site of the immunologic reaction is not critical to the chain of events, it is conceivable that the Shwartzman reaction may lead to destruction of the kidneys after transplantation of other organs.

\section{Cadaveric Transplantation}

A cadaveric renal homograft was first transplanted in Denver in April 1963. This recipient, as well as the next two, died within 39 days. The kidneys either functioned poorly or not at all. No more cadaveric transplantations were performed for more than two years.

The program was reopened in November 1965. From then until July 1967, 12 patients received as their primary homograft the kidney of a blood group compatible cadaver. In each case, a minimum followup of eight months is available.

Six of these 12 recipients died after $13,10,8,3 \frac{1}{2}, 3 \frac{1}{2}$, and 3 months. The other six are still alive after 27, 24, 15, 10, 9, and 8 months. However, one of the latter patients required transplant nephrectomy and regrafting one year after receipt of his first kidney; another lost his homograft after a year and is presently anephric 15 months post-transplantation.

The last six patients in this series received ALG therapy for the first several postoperative months. In all cases, the donor-recipient histocompatibility matches as determined by Terasaki were poor. Two of the recipients who had received their kidneys from a common cadaveric donor, died within a one day interval more than three months postoperatively. Death was caused by pulmonary emboli. The homografts had little or no evidence of rejection.

The other four patients including one with preformed lymphocytotoxic antibodies had good or excellent renal function during the 
four month period of ALG therapy. After its discontinuance, all have had evidence of slow but progressive rejection.

Other groups with much more extensive experience in cadaveric transplantation have repeatedly expressed optimism about the bright future of this approach $[6,27,35,36,45]$. It is a point of view with which few would disagree especially since the prospects of transplanting livers, lungs, and hearts will depend upon the use of cadaveric organs. Nevertheless, it is worth emphasizing that the costs in mortality, morbidity, and rehospitalization have been high in all centers. Furthermore, survival exceeding four years with continuous function of non-related renal homografts is rare. To our knowledge there are only four patients whose courses have been this long; one of Dr. W. Goodwin who was treated at UCLA in June 1963, another who has been followed by Dr. D. Hume of Richmond since August of that year, and two more who were in our Series 1.

\section{Ribonucleic Acid (RNA) Perfusion}

Many of the problems of organ transplantation could be minimized if it were possible to mitigate graft rejection by modifying the transplanted tissue rather than the host immunologic response. Efforts to achieve this objective have been unsuccessful with occasional possible exceptions $[2,21,30]$ of which the most intriguing was described by Jolley, Hinshaw, and Peterson [30]. They reported that rabbit skin grafts which were first immersed in homologous ribonucleic acid (RNA) and then transplanted to recipient animals which were given intravenous RNA had a survival four times longer than controls. The role of the preliminary soaking was not analyzable in these experiments, but the authors also reported that human skin homografts subjected only to RNA soaking had unusually protracted viability when placed upon patients with burns [31].

In our laboratories similar attempts to "pre-treat" whole organ homografts have been made in dogs by perfusing kidneys for about 30 min with RNA prepared by phenol extraction from the spleens of the prospective recipients (autologous RNA) or other dogs (homologous RNA). After transplantation to unmodified recipients, about one fourth of these life sustaining organs had prolonged homograft viability [14]. Maximum survival of recipients, which were subjected to simultaneous removal of their own kidneys, was 123 days. The mean survival in a group of 40 recipients was more than 20 days as 
opposed to approximately 10 days in 30 control animals. Furthermore, there were seven homografts of the 40 which had no histologic evidence of rejection whereas all the control homografts had the typical findings of unmodified rejection. The protection afforded by recipient specific RNA was not significantly different from that obtained with homologous RNA.

The foregoing effect was not increased by the addition of a supposed RNase inhibitor, DEAE-dextran, but it was abolished by the addition of commercial RNase. The treatment of renal autografts with homologous RNA did not result in their rejection. The latter finding, and the fact that the results after homotransplantation were equivalent with either homologous or autologous RNA, suggest that the homograft protection was not due to RNA-induced changes in the genetic characteristics of the cells.

The significance of the foregoing findings is quite unclear since a logical explanation for the surprising results is not available, and because the degree of homograft protection was relatively limited. It will be of interest in laboratory experiments to determine whether or not such graft conditioning can be advantageously combined with effective host immunosuppression.

\section{Liver Transplantation}

Until last year, the kidney was the only vital organ which had been transplanted with resulting significant prolongation of life. There had been nine attempts at orthotopic liver transplantation; seven in Denver $[70,80]$, and one each in Boston [53] and Paris [10]. Two of these patients had succumbed within a few hours after operation, and none had lived for longer than 23 days.

This dismal picture has changed within the last nine months, inasmuch as six consecutive children treated with orthotopic liver transplantation from July 1967 to February 1968 all passed through this previously lethal operative and postoperative period. Two of the patients are still alive after 8 and $1 \frac{1 / 2}{2}$ months respectively; the others died after $2,3 \frac{1}{2}, 4 \frac{1}{2}$, and $6 \frac{1}{2}$ months. The better results were the product of several improvements in care as reported elsewhere [71].

First, a very efficient technique of preservation had been developed in dogs which permitted livers to be stored for 8 to 24 hours and then successfully transplanted as orthotopic homografts [3]. The method which combined hypothermia, low flow perfusion with diluted blood, 
and hyperbaric oxygenation, was used in the clinical cases for several hours after death of the donors and until the recipients could be prepared. Good immediate hepatic function was obtained in each case (fig. 11).

In each of these cases, the compatibility of the donor and recipient white cell antigens was studied by TERASAKI in advance of operation. A good match with compatibility in all six currently recognized components of the recently defined HLA system [90] was present only in one case. In three, there were breeches in one major antigen group and in the other two there were mismatches in two of the six groups.

A conservative attitude toward immunosuppression was taken during the early postoperative period, particularly in the dosages of

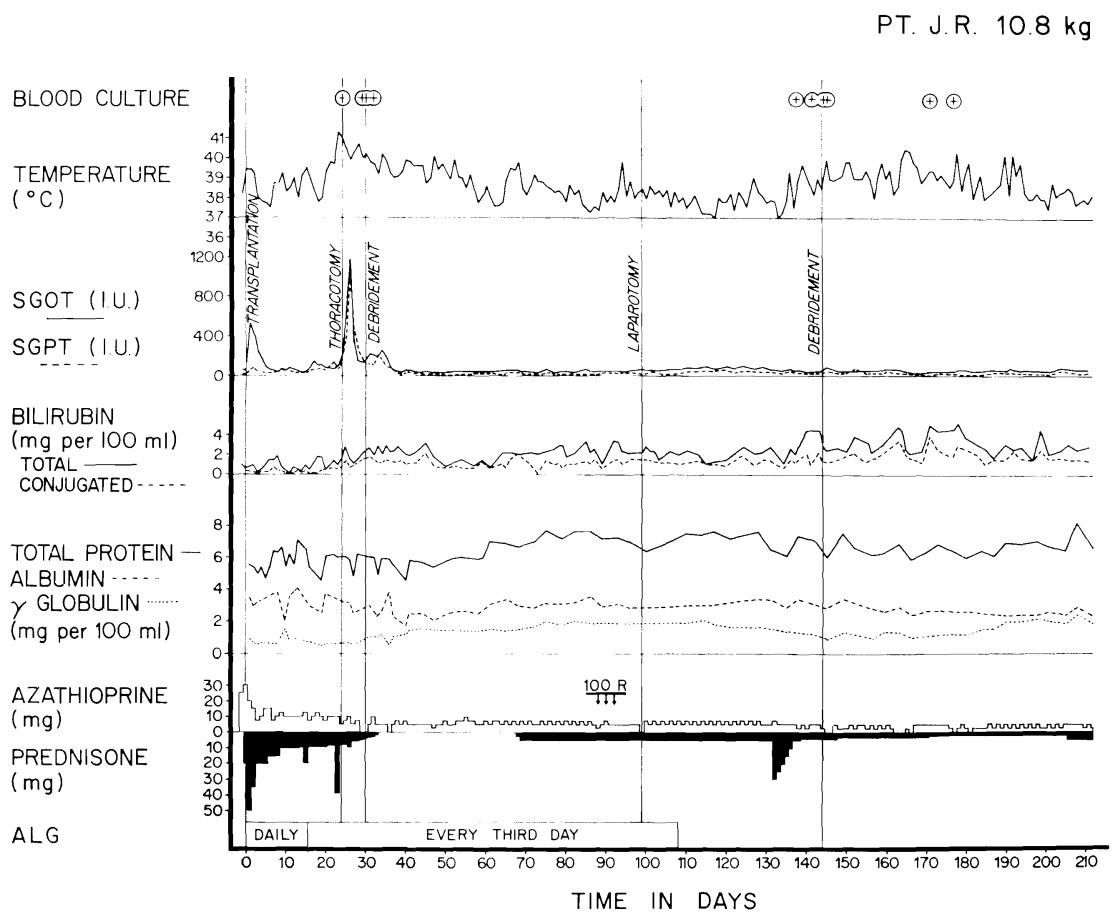

Fig. 11. Course of a $1 \frac{1}{2}$ year old girl who was treated with orthotopic hepatic homotransplantation. The indication for the operation was a hepatoma. Note the essentially stable liver function except at the times of septic liver infarctions which were treated with debridement. The septicemia, indicated by encircled crosses, was with various gram negative rods or candida albicans. The thoractomy was for an unexpanded right upper lobe. The laparotomy was for excision of a tumor recurrence. 
azathioprine (fig. 11). High initial doses of prednisone were given but rapidly reduced. Finally, heterologous antilymphocyte globulin (ALG) was administered in a course (fig. 11) similar to that described earlier after renal homotransplantation.

The six recipients were all infants. The indication for operation was a hepatoma in the first patient and extrahepatic biliary atresia in the other five. In all but one case, the early convalescence was remarkably rapid. Pre-existing jaundice was quickly cleared. Eating was begun on the second to fourth postoperative days.

A specific life threatening complication was encountered in five of the six patients. From two days to two months postoperatively, septicemia with gram negative microorganisms interrupted recovery. This was accompanied by high increases in SGOT and SGPT (fig. 11) and eventually septic infarctions within the liver were found. Liver scans showed filling defects which involved the right lobe (fig. 12).

In one case, the development of hepatic sepsis was not surprising inasmuch as a serious technical accident could be implicated. The homograft had been found to have a double arterial supply and the two vessels were anastomosed to the terminal right and left branches of the recipient hepatic artery. The artery to the right lobe thrombosed on the second postoperative day eventually necessitating a partial right lobectomy. In the four other children the complication occurred after a benign early postoperative course. Two of the latter patients who died from this complication were also found at autopsy to have thrombosed right hepatic arteries.

The unusual susceptibility of the transplanted liver to invasion by enteric organisms is not surprising in view of its perfusion by splanchnic venous blood, as well as the necessity for connecting its biliary drainage system to the intestinal tract. However, the precise pathogenetic events of the septic liver infarctions can only be speculated upon in the individual cases. In a recent analysis of the problem in dogs [4], any factor which caused liver necrosis, including the injury of rejection, was shown to predispose to liver abscess formation. It is possible that, in at least some of the clinical cases, the intensity of immunosuppression was inadequate, that the infarctions were a manifestation of the reduced blood flow known to accompany rejection [15], and that the bacterial invasion was a secondary event. In at least three of the patients, however, rejection did not seem to be severe when the right hepatic artery thrombosed. In these cases, the differentiation of mechanical from immunologic factors was not possible. 


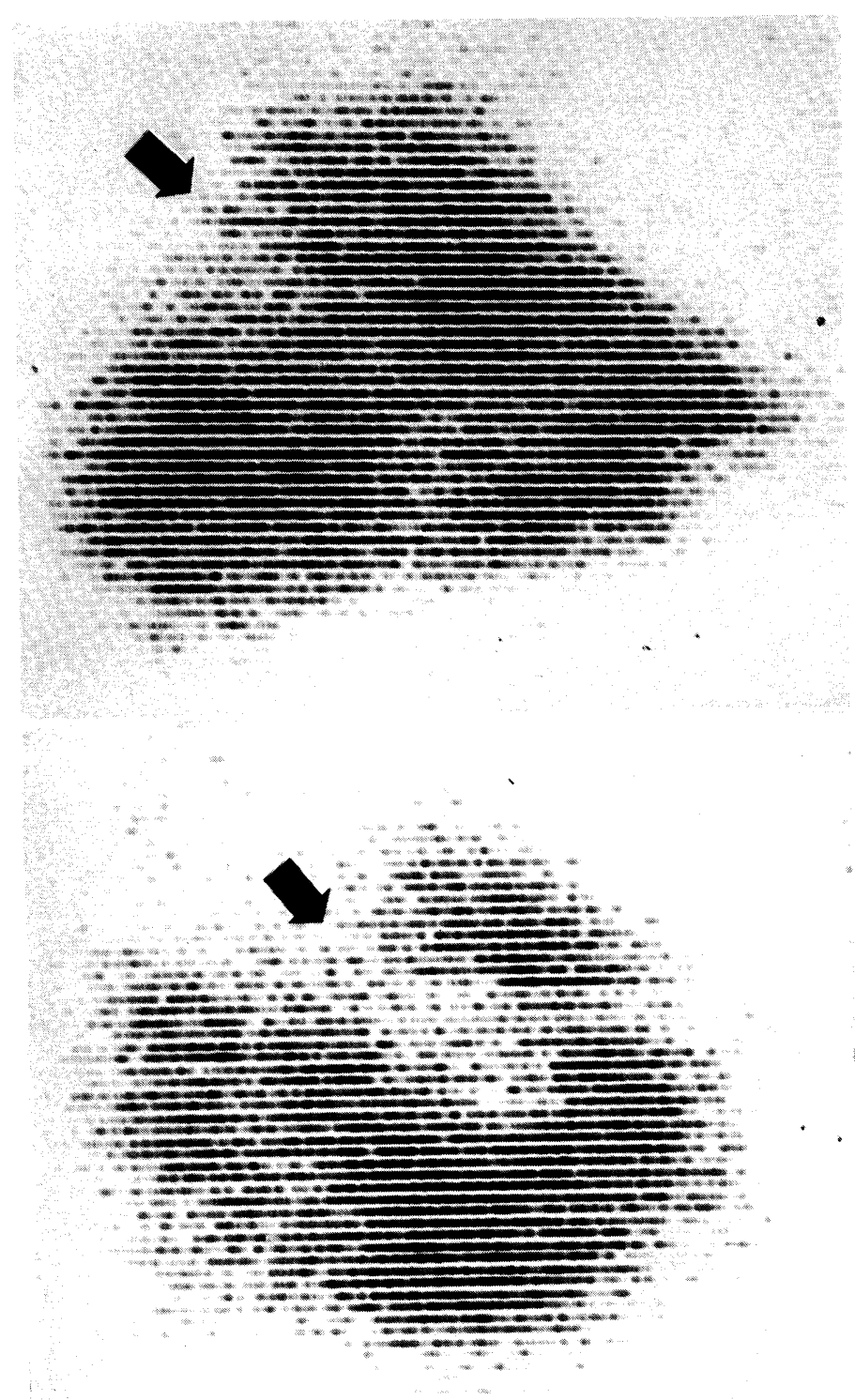

Fig. 12. Liver scan performed one month after hepatic homotransplantation in the $1 \frac{1 / 2}{2}$ year old patient whose course is depicted in figure 11. Anteroposterior (upper) as well as lateral views (lower) show large defect (arrows). Exploration revealed a septic infarct in the homograft. 
Once established in the clinical cases, the infected liver infarcts required aggressive therapy. Debridement and drainage were carried out through lateral incisions in the right 10th intercostal space, taking care to enter neither the chest nor abdomen. These local measures plus therapy with properly chosen antibiotics tided three patients over the crisis but two of these eventually died. Two other recipients died within a few days after the onset of the complication.

An alternative to orthotopic liver transplantation has also been given a clinical trial, namely transplantation of an auxiliary organ. Only five cases have been reported $[1,8,16]$ but it is known that many more have been attempted. The longest survival after auxiliary liver transplantation has been 34 days [16]. Analyses of the special physiologic and technical difficulties with this approach have been published [46], suggesting that it may be a less desirable procedure than the orthotopic operation.

\section{Summary}

Several separate issues in organ transplantation have been reviewed based upon our own experience with renal and liver transplantation. The topics surveyed include a reconsideration of rejection reversal and host-graft adaptation, projections of survival after renal homotransplantation in the past and today, the role of histocompatibility typing, improvements in immunosuppression, an evaluation of thymectomy, the development of neoplasms in post-transplantation patients, and the contribution of the Shwartzman reaction to "hyperacute rejection". In addition, a specific problem of hepatic sepsis after liver transplantation has been described.

\section{References}

1. Absolon, K.B.; Hagihara, P.F.; Griffen, W.O. and Lillehei, R.C.: Experimental and clinical heterotopic liver homotransplantation. Rev. int. Hépat. 15: 1481 (1965).

2. Bonmassar, E.; Franesconi, G.; Manzoni, S.C. and Perelli-Ercolini, M.: Chemical deletion of histocompatibility antigens. Homograft survival of rat skin treated with "Urethan" in vitro. Nature 209: 1141 (1966).

3. Brettschneider, L.; Daloze, P.M.; Huguet, C.; Porter, K.A.; Groth, C.G.; Kashiwagi, N.; Hutchison, D.E. and Starzl, T.E.: The use of combined preservation techniques for extended storage of orthotopic liver homografts. Surg. Gynec. Obstet. 126: 263 (1968).

4. Brettschneider, L.; Tong, J.L.; Boose, D.S.; Daloze, P.M.; Smith, G.V.; Huguet, C.; Blanchard, H.; Groth, C. G. and Starzl, T.E.: Specific bacteriologic problems after orthotopic liver transplantation in dogs and pigs. Arch. Surg. 97: 313 (1968).

5. Brown, E.; Seidel, W. and KolfF, W. J.: Hemolysis caused by pumps at flow rates of 2 liters. Trans. amer. soc. artif. Int. Organs 7: 350 (1961). 
6. Calne, R.Y.; Loughridge, L.; MacGillivray, J. B. and Swales, J.D.: Further observations on renal transplants in man from cadaveric donors. Brit. med. J. 2: 1345 (1966).

7. Ceppellini, R.; Curtoni, E.S.; Mattiuz, P.L.; Leigheb, G.; Visetti, M. and Colomвi, A.: Survival of test skin grafts in man: Effect of genetic relationship and of blood groups incompatibility. Ann. N.Y. Acad. Sci. 129: 421 (1966).

8. CRee, I. C.: A liver transplant. Minn. Med. 50: 1523 (1967).

9. Cross, A.M.; Leuchars, E. and Miller, J.F.A.P.: Studies on the recovery of the immune response in irradiated mice thymectomized in adult life. J. exp. Med. 119: 837 (1964).

10. Demirleau; Nourreddine; Vignes; Prawerman; Reizicinar; Larraud and Louvier: Tentative d'homograffe hepatique. Mém. Acad. Chir. (Paris) 90: 177 (1964).

11. Goodwin, W.E.; Kaufman, J.J.; Mims, M.M.; Turner, R.D.; Glassock, R.; Goldman, R. and Maxwell, M.M.: Human renal transplantation: Clinical experiences with 6 cases of renal homotransplantation. J. Urol. 89: 13 (1963).

12. Goodwin, W.E. and Martin, D. C.: Transplantation of the kidney. Urol. Surv. 13: 229 (1963).

13. Gray, J.G.; Monaco, A.P. and Russell, P.S.: Heterologous mouse anti-lymphocyte serum to prolong skin homografts. Surg. Forum 15: 142 (1964).

14. Groth, C. G.; Porter, K.A.; Daloze, P.M.; Huguet, C.; Smith, G.V.; BrettSCHNEIDER, L. and STARzL, T.E.: The effect of ribonucleic acid perfusion on canine kidney and liver homograft survival. Surgery $64: 31$ (1968).

15. Groth, C.G.; Porter, K.A.; Otte, J.B.; Daloze, P.M.; Marchioro, T.L.; BRETTSCHNEIDER, L. and StARzL, T.E.: Studies of blood flow and ultrastructural changes in rejecting and non-rejecting canine orthotopic liver homografts. Surgery 63: 658 (1968).

16. Halgrimson, C.G.; Marchioro, T. L.; Faris, T.D.; Porter, K.A.; Peters, G. N. and StarzL, T.E.: Auxiliary liver transplantation. Effect of host portacaval shunt. Arch. Surg. 93: 107 (1966).

17. Hamburger, J.; Vaysse, J.; Crosnier, J.; Tubiana, M.; Lalanne, C. M.; Antoine, B.; Auvert, J.; Soulier, J.A.; Dormont, J.; Salmon, C.; Maisonnet, M. and AmIEL, J.L.: Transplantation d'un rein entre jumeaux non-monozygotes après irradiation du receveur: Bon fonctionnement au quatrième mois. Presse Méd. 67: 1771 (1959).

18. Hamburger, J.; Crosnier, J.; Dormont, J.; Reveillaud, R. J.; Hors, J.H. and Alsina, J.: Homotransplantation renale humaine. Résultats personnels chez 52 malades. I. Téchniques et résultats d'ensemble. Presse Méd. 73: 2793 (1965).

19. Hamburger, J.; Vaysse, J.; Crosnier, J.; Auvert, J.; Lalanne, C.M. and Hopper, J., Jr.: Renal homotransplantation in man after radiation of the recipient: Experience with six cases since 1959. Amer. J. Med. 32: 854 (1962).

20. Harlan, W.R., Jr.; Holden, K.R.; Williams, G. M. and Hume, D. M.: Proteinuria and nephrotic syndrome in rejection of kidney transplants. New Engl. J. Med. 277: 769 (1967)

21. Hellman, K.; Duke, D.I. and Tucker, D.F.: Prolongation of skin homograft survival by Thalidomide. Brit. med. J. 2: 687 (1965).

22. Hill, R.B., Jr.; Dahrling, B.E.; Starzl, T.E. and Rifkind, D.: Death after transplantation: An analysis of 60 cases. Amer. J. Med. 42: 327 (1967).

23. Histocompatibility Testing: National Academy of Sciences-National Research Council (Publ. 1229) Washington, D.C. (1965).

24. Hiтснсоск, C.: Personal Communication (March 10, 1968).

25. HJort, P.F. and Rapaport, S.I.: The Shwartzman reaction: Pathogenetic mechanisms and clinical manifestations. Ann. Rev. Med. 16: 135 (1965). 
26. Hogman, C.F.: Blood group antigens A and B determined by means of mixed agglutination on cultured cells of human fetal kidney, liver, spleen, lung, heart and skin. Vox. Sang. 4: 12 (1959).

27. Hume, D.M.; Lee, H.M.; Williams, G.M.; White, J.O.; Ferre, J.; Wolf, J.S.; Prout, G.R., Jr.; Slapak, M.; O’Brien, J.; Kilpatrick, S. J.; Kauffman, H.M., Jr. and Cleveland, R. J.: Comparative results of cadaver and related donor renal homografts in man, and immunologic implications of the outcome of second and paired transplants. Ann. Surg. 164: 352 (1966).

28. Ifasaki, Y.; Porter, K.A.; Amend, J.; Marchioro, T.L.; Zuhlke, V. and Starzl, T.E.: The preparation and testing of horse antidog and antihuman antilymphoid plasma or serum and its protein fractions. Surg. Gynec. Obstet. 124: 1 (1967).

29. JEEJEEBHOY, H.F.: Effects of rabbit anti-rat lymphocyte plasma on immune response of rats thymectomized in adult life. Lancet $i i: 106$ (1965).

30. Jolley, W.B.; Hinshaw, D.B. and Peterson, M.: Effect of ribonucleic acid on homograft survival. Surg. Forum 12: 99 (1961).

31. Jolley, W.B. and Hinshaw, D.B.: Basic studies on homograft acceptance including early clinical results. Amer. J. Surg. 112: 308 (1966).

32. Kashiwagi, N.; Brantigan, C. O.; Brettschneider, L.; Groth, C. G. and Starzl, T.E.: Clinical reactions and serologic changes following the administration of heterologous antilymphocyte globulin to human recipients of renal homografts. Ann. int. Med. 68: 275 (1968).

33. Kashiwagi, N.; Groth, C.G.; Amend, J.R.; Gecelter, L.; Blanchard, H. and STARZL, T.E.: Improvements in the preparation of heterologous antilymphocyte globulin with special reference to absorption and DEAE-cellulose batch production. Surgery (in press, 1968).

34. KIDD, E. E.: Bacterial contamination of dialyzing fluid of artificial kidney. Brit. med. J. 1: 880 (1964).

35. Kincaid-Smith, P.; Marshall, V.S.; Methew, T.H.; Eremin, J.; Brown, R. B.; Johnson, N.; Lovell, R.R.H.; McLeish, D.G.; Fairley, K.F.; Allcock, E.A. and EwING, M.R.: Cadaveric renal transplantation. Lancet ii: 59 (1967).

36. Kiser, W.S.; Straffon, R.A.; Hewitt, C. B.; Stewart, B.H.; Nakamoto, S. and KolfF, W. J.: Clinical experience with one hundred twenty-one human kidney transplants. Amer. Surg. 33: 304 (1967).

37. Kissmeyer-Nielsen, F.; Olsen, S.; Petersen, V.P. and Fjeldborg, O.: Hyperacute rejection of kidney allografts associated with pre-existing humoral antibodies against donor cells. Lancet $i i$ : 662 (1966).

38. Kountz, S.L.; Williams, M.A.; Williams, P.L.; Kapros, C. and Dempster, W. J.: Mechanism of rejection of homotransplanted kidneys. Nature (Lond.) 199: 257 (1963).

39. Kountz, S. L.; Laub, D.R. and Cohn, R.: Detecting and treating early renal homotransplant rejection. J. amer. med. Ass. 191 : 997 (1965).

40. Kuss, R.; Legraine, M.; Mathé, G.; Nedy, R. and Camey, M.: Homologous human kidney transplantation. Experience with six patients. Postgrad. med. J. 38: 528 (1962).

41. Lee, H.M.; Hume, D.M.; Vredevoe, D. L.; Mickey, M.R. and Terasaki, P.I.: Serotyping for homotransplantation. IX. Evaluation of leukocyte antigen matching with the clinical course and rejection types. Transplantation 5: 1040 (1967).

42. Lee, L. and Stetson, C.A.: The local and generalized Shwartzman phenomena. In: The inflammatory process, pp. 791-817 (Eds.) L. GrANT and R. T. McCluskey (Academic Press, New York 1965).

43. Lerner, R.A.; Glassock, R. J. and Dixon, F. J.: The role of antiglomerular basement membrane antibody in the pathogenesis of human glomerulonephritis. J. exp. Med. 126: 989 (1967). 
44. Levey, R.H. and Medawar, P.B.: Nature and mode of action of antilymphocyte antiserum. Proc. nat. Acad. Sci. (U.S.A.) 56: 1130 (1966).

45. Martin, D.C.; Goodwin, W.E.; Kaufman, J.J.; Mims, M.M.; Goldman, R.; Rubini, M. and Gonick, H.: Ninety-two kidney transplants: Results, lessons learned, future prospects. J. Urol. (in press, 1968).

46. Marchioro, T.L.; Porter, K.A.; Dickinson, T.C.; Faris, T.D. and Starzl, T.E.: Physiologic requirements for auxiliary liver homotransplantation. Surg. Gynec. Obstet. 121: 17 (1965).

47. McGavic, J.D.; Knight, P.R.; Tomkiewicz, Z.M.; Alexandre, G.P.J. and Murray, J.E.: Analysis of mechanisms of drug induced tolerance in canine renal homotransplants. Surg. Forum 14: 210 (1963).

48. Merrill, J.P.; Murray, J.E.; Harrison, J.H.; Friedman, E.A.; Dealy, J.B. and Dammin, G. J.: Successful homotransplantation of the kidney between nonidentical twins. New Engl. J. Med. 262: 1251 (1960).

49. Miller, J.F.A.P.: Immunological significance of the thymus of the adult mouse. Nature (Lond.) 195: 1318 (1962).

50. Miller, J.F.A.P.: Effect of thymectomy in adult mice on immunological responsiveness. Nature (Lond.) 208: 1337 (1965).

51. Monaco, A.P.; Wood, M.L. and Russell, P.S.: Effect of adult thymectomy on the recovery from immunological depression induced by heterologous antilymphocyte serum. Science 149: 432 (1965).

52. Monaco, A.P.; Wood, M.L.; Van Der Werf, B.A. and Russell, P.S.: Effect of antilymphocyte serum in mice, dogs and man. In: Antilymphocytic Serum, pp. 111134. (Eds.) Wolstenholme, G. E. W. and O'Connor, M. (J. and A. Churchill Ltd., London 1967).

53. Moore, F.D.; Birtch, A.G.; Dagher, F.; Veith, F.; Krisher, J.A.; Order, S.E.; Shucart, W.A.; Dammin, G. J. and Couch, N.P.: Immunosuppression and vascular insufficiency in liver transplantation. Ann. N. Y. Acad. Sci. 120:729 (1964).

54. Murray, J.E.; Sheil, A.G.R.; Moseley, R.; Knight, P.R.; McGavic, J.D. and Dammin, G.J.: Analysis of mechanism of immunosuppressive drugs in renal homotransplantation. Ann. Surg. 160: 449 (1964).

55. Murray, J.E.; Wilson, R.E. and O'Connor, N.E.: Evaluation of long functioning human kidney transplants. Surg. Gynec. Obstet. 124: 509 (1967).

56. O'Brien, J.P. and Hume, D.M.: Membranous glomerulonephritis in two human renal homotransplants. Ann. int. Med. 65: 504 (1966).

57. OgDen, D.A.: Donor and recipient function two to four years after renal homotransplantation. A paired study of 28 cases. Ann. int. Med. 67: 998 (1967).

58. Ogden, D.A.; Porter, K.A.; Terasaki, P.I.; Marchioro, T.L.; Holmes, J.H. and StARzL, T.E.: Chronic renal homograft function: Correlation with histology and lymphocyte antigen matching. Amer. J. Med. 43 : 837 (1967).

59. Petersen, V.P.; Olsen, S.; Kissmeyer-Nielsen, F. and FJeldborg, O.: Transmission of glomerulonephritis from host to human kidney allotransplant. New Engl. J. Med. 275: 1269 (1966).

60. Porter, K.A.; Andres, G.A.; Calder, M.W.; Dosseter, J.B.; Hsu, K.C.; Rendall, J.M.; Seegal, B.C. and Starzl, T.E.: Human renal transplants. II. Immunofluorescent and immunoferritin studies. Lab. Invest. 18: 159 (1968).

61. Porter, K.A.; Rendall, J.M.; Stolinski, C.; Terasaki, P.I.; Marchioro, T. L. and Starzl, T.E.: Light and electron micrographic study of biopsies from 33 human renal allografts and an isograft $1 \frac{3}{4}$ to $2 \frac{1}{2}$ years after transplantation. Ann. N. Y. Acad. Sci. 129: 615 (1966).

62. Porter, K.A.: Pathological changes in transplanted kidneys. In: Experience in renal transplantation, pp. 299-359 (Ed.) T.E. STARzL (W.B. Saunders Co., Philadelphia 1964). 
63. Rapaport, F.T.; Dausset, J.; Hamburger, J.; Hume, D.M.; Kano, K.; Williams, G.M. and Mrlgrom, F.: Serologic factors in human transplantation. Ann. Surg. 166: 596 (1967).

64. Retik, A.B.; Hollenberg, N.K.; Rosen, S.M.; Merrill, J.P. and Murray, J.E.: Cortical ischemia in renal allograft rejection. Surg. Gynec. Obstet. 124: 989 (1967).

65. Rosen, S.M.; Retik, A.B.; Hollenberg, N.K.; Merrill, J.P. and Murray, J.E.: Effect of immunosuppressive therapy on the intrarenal distribution of blood flow in dog renal allograft rejection. Surg. Forum 17: 233 (1966).

66. Schwartz, R.; Schwartz, J.A.; Armstrong, M.Y.K. and Beldotti, L.: Neoplastic sequelae of allogenic disease. I. Theoretical considerations and experimental design. Ann. N. Y. Acad. Sci. 129: 804 (1966).

67. Shackman, R.; Dempster, W. J. and Wrong, O.M.: Kidney transplantation in the human. Brit. J. Urol. 35: 222 (1963).

68. Sherman, J.D.: Effect of thymectomy on the golden hamster, III. Studies on adult thymectomized hamsters. J. lab. clin. Med. 67: 273 (1966).

69. Starzl, T.E.: Experience in renal transplantation (W. B. Saunders Co., Philadelphia 1964).

70. Starzl, T.E.; Brettschneider, L. and Groth, C.G.: Recent developments in liver transplantation. In: Advance in transplantation (Eds.) Dausset, J., HaMBURger, J. and MathÉ, G, pp. 633-637 (Munksgaard Ltd., Copenhagen 1968).

71. Starzl, T.E.; Groth, C.G.; Brettschneider, L.; Moon, J. B.; Fulginiti, V.A.; Cotton, E.K. and Porter, K.A.: Extended survival in three cases of orthotopic homotransplantation of the human liver. Surgery 63: 549 (1968).

72. Starzl, T.E.; Groth, C.G.; Terasaki, P.I.; Putnam, C.W.; Brettschneider, L. and Marchioro, T.L.: Heterologous antilymphocyte globulin, histocompatibility matching, and human renal homotransplantation. Surg. Gynec. Obstet. 126: 1023 (1968).

73. Starzl, T.E.; Lerner, R.A.; Dixon, F. J.; Groth, C.G.; Brettschneider, L. and Terasaki, P.I.: The Shwartzman reaction after human renal transplantation. New Engl. J. Med. 278: 642 (1968).

74. Starzl, T.E.; Marchioro, T.L.; FAris, T.D.; McCardle, R. J. and Iwasaki, Y.: Avenues of future research in homotransplantation of the liver: With particular reference to hepatic supportive procedures, antilymphocyte serum and tissue typing. Amer. J. Surg. 112: 391 (1966).

75. Starzl, T.E.; Marchioro, T.L.; Hermann, G.; Brittain, R.S. and Waddell, W.R.: Renal homografts in patients with major donor-recipient blood group incompatibilities (Addendum). Surgery 55: 195 (1964).

76. Starzl, T.E.; Marchioro, T.L.; Porter, K.A.; Iwasaki, Y. and Cerilli, G. J.: The use of heterologous antilymphoid agents in canine renal and liver homotransplantation, and in human renal homotransplantation. Surg. Gynec. Obstet. 124 : 301 (1967).

77. Starzl, T.E.; Marchioro, T.L.; Rifkind, D.; Holmes, J.H.; Rowlands, D. T., Jr. and WADDELL, W.R.: Factors in successful renal transplantation. Surgery 56 : 296 (1964).

78. Starzl, T.E.; Marchioro, T.L.; Terasaki, P.I.; Porter, K.A.; Faris, T.D.; Herrmann, T.J.; Vredevoe, D.L.; Hutt, M.P.; Ogden, D.A. and Waddell, W.R.: Chronic survival after human renal homotransplantation. Ann. Surg. 162: 749 (1965).

79. Starzl, T.E.; Marchioro, T.L.; Talmage, D.W. and Waddell, W.R.: Splenectomy and thymectomy in human renal homotransplantation. Proc. Soc. exp. biol. Med. 113: 929 (1963). 
80. Starzl, T.E.; Marchioro, T.L.; von Kaulla, K.; Hermann, G.; Brittain, R.S. and WADDELL, W.R.: Homotransplantation of the liver in humans. Surg. Gynec. Obstet. 117: 659 (1963).

81. Starzl, T.E.; Porter, K.A.; Iwasaki, Y.; Marchioro, T.L. and Kashiwagi, N.: The use of antilymphocyte globulin in human renal homotransplantation. In: Antilymphocytic serum, pp. 4-34. (Eds.) Wolstenholme, G.E. W. and O'Connor, M. (J. and A. Churchill Ltd., London 1967).

82. Starzl, T.E.; Marchioro, T.L. and Waddell, W.R.: The reversal of rejection in human renal homografts with subsequent development of homograft tolerance. Surg. Gynec. Obstet. 117: 385 (1963).

83. Stickel, D. L.; Amos, D. B.; Zmijewski, C. M.; GlenN, J.F. and Robinson, R.R.: Human renal transplantation with donor selection by leucocyte typing. Transplantation 5: 1024 (1967).

84. Subramanian, V. and Gans, H.: Impaired reticuloendothelial function following extracorporeal circulation and its relationship to blood trauma. Arch. Surg. 97: 330 (1968).

85. Szulman, A.E.: The histological distribution of the blood group substances A and B in man. J. exp. Med. 111: 785 (1960).

86. TAYLOR, R. B.: Decay of immunological responsiveness after thymectomy in adult life. Nature (Lond.) 208: 1334 (1965).

87. Terasaki, P.I.; Marchioro, T.L. and Starzl, T.E.: Sero-typing of human lymphocyte antigens: Preliminary trials on long-term kidney homograft survivors. In: Histocompatibility testing, pp. 83-95 Nat. Acad. Sci. (National Research Council, Washington, D.C. 1965).

88. Terasaki, P.I.; Porter, K.A.; Marchioro, T.L.; Mickey, M.R.; Vredevoe, D.L.; FARIS, T.D. and StarzL, T.E.: Serotyping for homotransplantation. VII. Selection of kidney donors for 32 recipients. Ann. N. Y. Acad. Sci. 129: 500 (1966).

89. Terasaki, P.I.; Trasher, D.L. and Hauber, T.M.: Serotyping for homotransplantation. XIII. Immediate kidney transplant rejection and associated preformed antibodies. In: Advance in transplantation, pp. 225-229 (Munksgaard, Copenhagen 1968).

90. Terasaki, P.I.; Vredevoe, D.L. and Mickey, M.R.: Serotyping for homotransplantation. X. Survival of 196 grafted kidneys subsequent to typing. Transplantation 5: 1057 (1967).

91. Terasaki, P.I.; Vredevoe, D.L.; Porter, K.A.; Mickey, M.R.; Marchioro, T.L.; Faris, T.D.; HerrmanN, T.J. and Starzl, T.E.: Serotyping for homotransplantation. V. Evaluation of a matching scheme. Transplantation 4: 688 (1966).

92. Thоmas, L. and Good, R.A.: The effect of cortisone on the Shwartzman reaction. J. exp. Med. 95: 409 (1952).

93. van Rood, J. J., van Leeuwen, A.; Schippers, A.; Ceppellini, R.; Mattiuz, P. L. and CURToni, S.: Leucocyte groups and their relation to homotransplantation. Ann. N. Y. Acad. Sci. 129: 467 (1966).

94. von Kaulla, K.N.; von Kaulla, E.; Wasantapruck, K.S.; Marchioro, T.L. and STARzL, T.E.: Blood coagulation in uremic patients before and after hemodialysis and transplantation of the kidney. Arch. Surg. 92: 184 (1966).

95. Waksman, B.H.; Arbouys, S. and Arnason, B.G.: The use of specific "lymphocyte antisera" to inhibit hypersensitivity reactions of the delayed type. J. exp. Med. 114: 997 (1961)

96. Williams, G.M.; Lee, H.M.; Weymouth, R.F.; Harlan, W.R.; Jr.; Holden, K.R.; Stanley, C.M.; Millington, G.A. and Hume, D.M.: Studies in hyperacute and chronic renal homograft rejection in man. Surgery 62: 204 (1967).

97. Williams, G.M.; Hume, D.M.; Kano, K. and Milgrom, F.: Acute vasculitis in human renal transplants (Personal communication, January 6, 1968). 
98. Williams, G.M.; White, H. J.O. and Hume, D.M.: Factors influencing the longterm functional success rate of human renal allografts. Transplantation $5: 837$ (1967).

99. Wilson, W.E.C. and Kirkpatrick, C.H.: Immunological aspects of renal homotransplantation. In: Experience in renal transplantation, pp. 239-261 (Ed.) STARzL, T.E. (W.B. Saunders Co., Philadelphia 1964).

100. Wolstenholme, G.E.W. and O'Connor, M. (Eds.): Antilymphocytic serum (J. and A. Churchill Ltd., London 1967).

101. WoodrufF, M.F.: Experience with transplantation of the kidney in man. Ann. roy. Coll. Surg. Engl. 39: 178 (1966).

102. Woodruff, M.F.A. and Anderson, N.F.: Effect of lymphocyte depletion by thoracic duct fistula and administration of antilymphocyte serum on the survival of skin homografts in rats. Nature (Lond.) 200: 702 (1963).

103. Woodruff, M.F.A. and WoodruFf, H.G.: The transplantation of tissue: with special reference to auto- and homotransplants of thyroid and spleen in the anterior chamber of the eye, and subcutaneously, in guinea pigs. Phil. Trans. B 234: 559 (1950).

Authors' address: Prof. Dr. T.E. Starzl, Dr. C.G. Groth, Dr. L. Bretrschneider, Dr. G.V. Smith, Dr. I. Penn and Dr. N. Kashiwagi, Department of Surgery, University of Colorado School of Medicine and Veterans Administration Hospital, Denver, Col. (USA). 